The retina shows atrophic changes in the ganglion cell and nerve fibre layers, and there is cystic degeneration at the ora serrata and periphery of the retina. 'The lamina cribrosa is displaced backwards.

Diagnosis.-Sclerosing keratitis profunda. Secondary glaucoma.

Commentary. - Pathologically the corneal lesion has predominant chronic inflammatory characters, such degenerative changes as are present are probably secondary to this.

\title{
GRANULOMA OF THE BULBAR SUBCONJUNCTIVAL TISSUE ARISING FROM AN IMBEDDED CILIUM
}

\author{
BY \\ F. W. G. SMITH \\ LONDON
}

WHILE reports on the presence of cilia in the interior of the eye are comparatively common a study of recent literature does not appear to disclose a case of the type described in this note.

History. The patient, a lady aged 66 years, complained of a localised swelling on the right eyeball which had been present for about six weeks and was gradually increasing in size. She volunteered the information that the swelling appeared to be quite hard on palpation through the lid and at times it was slightly tender. She had been under treatment for episcleritis for some weeks but the condition was showing no tendency to improve. The eye had been quite normal previous to the present complaint. Her own history and that of her family was quite satisfactory, she had one child. She had been engaged in the teaching profession for forty-five years.

I enquired very carefully into the history of the eye trouble but there was no suggestion of trauma (of this the patient was quite definite) nor of contact with caterpillars; one of the infective or possibly malignant conditions giving rise to what is shown in the painting was suspected to be the cause of her complaint.

The vision was 6/6 and J.1 in each eye. Glasses were worn for reading only. The fundi appeared to be normal and there were no corneal precipitates or signs of iritis present.

An unpigmental mass of about $4 \mathrm{~mm}$. by $1.5 \mathrm{~mm}$. in height was present under the bulbar conjunctiva; it was situated about $4 \mathrm{~mm}$. from the limbus on the outer side. There were five large vessels radiating from the growth, which appeared to be adherent to both the conjunctiva and the sclera and it was of a firm 
consistency, solid and not cystic; part of the growth appearef to be slightly gelatinous but the remainder was opaque.

The pre-auricular gland was not enlarged. A search was made for similar foci in both eyes without result. The mass did noff stain with fluorescein.

The growth was examined carefully with loupe and oblique illumination and in the semi-transparent part a curious appearब ance was noted which suggested that a body of a different refractive index to the gelatinous part was imbedded within it.

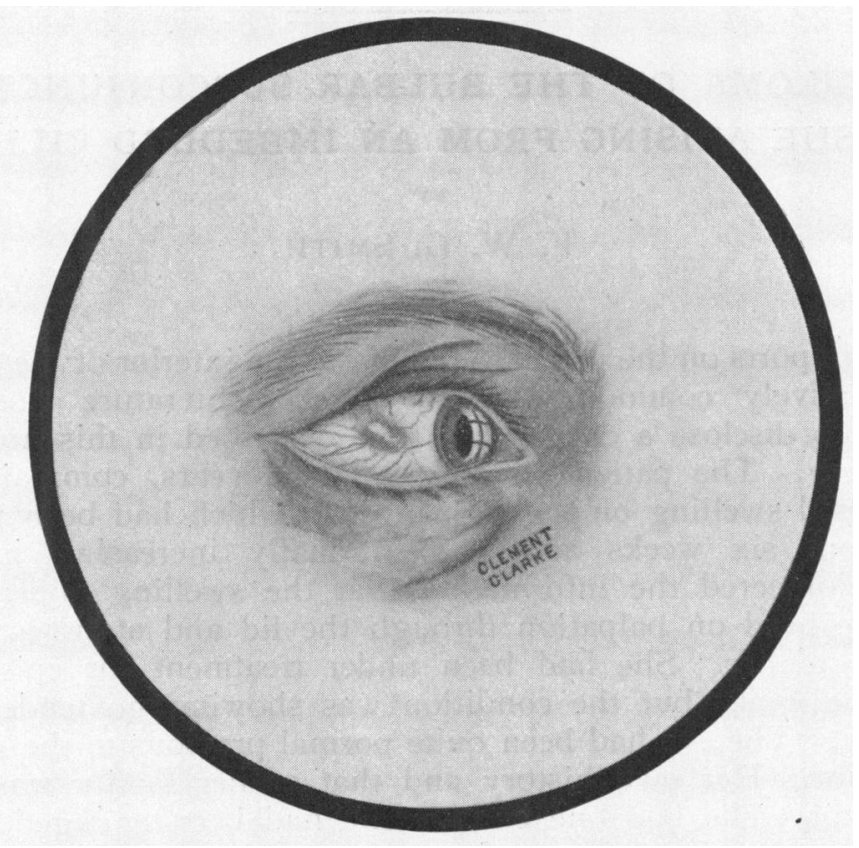

Search with a needle enabled a cilium to be removed with little difficulty : the cilium was of the same size and appearance as the patient's own but bleached at its extremity.

The whole condition rapidly subsided and there was little to be seen in a week's time. The painting was made after the removal of the cilium and shows rather more injection round the. growth and a smaller mass than was present when the case wast seen originally.

Subsequently the patient volunteered the following explanav tion as to how the condition might have occurred. About seve⿳⺈ weeks previously, while sitting in front of a coke fire in an oper grate, she heard a slight explosion from the fire and felt a stinging 
in her right eye; she considers now that it was from that time that her eye began to give her trouble and the suggestion put forward was that moisture in a piece of coke caused the explosion which drove a small piece of coke with an eyelash through the conjunctiva.

J. Stewart Barrie ${ }^{1}$ has reported a case where bristles worked their way under the conjunctiva causing swellings in a man employed in a brush factory. The swellings subsided when the man ceased to be engaged in this particular form of work.

A. MacRae ${ }^{2}$ has described a case of subconjunctival granulomata, which were not adherent to the sclera. In these the pathological report showed chronic granulation tissue but further examinations apparently did not elucidate their causation with certainty.

Localised abscesses of the sclera would seem to be a more generally recognised condition recently; Beigelman ${ }^{3}$ in a study of scleral cysts states that their origin is traumatic in the majority of case; the conjunctiva is usually freely movable over these cysts.

Würdemann $n^{4}$ notes that hayseeds or husks can remain for some time in the conjunctiva without causing irritation and in another instance he quotes Schwartz who says that cilia and other foreign bodies may be carried into wounds quite frequently but that it is rare for them to remain inert. Praun is quoted, also, who showed that foreign bodies in the sclera occur about two hundred times less frequently than in the cornea.

Scleral foreign bodies were usually the result of explosions. Würdemann states that intra-ocular cilia eventually give rise to trouble and he advises early removal, an opinion which would not appear to be entirely unanimous.

The case described in this note emphasises the fact that epibulbar growths merit careful examination with the slit-lamp. In some cases complete excision with the object of removing any contained foreign body would appear to be worth consideration: this might be done instead of removing a portion only for a pathological report on the growth. Such treatment is suggested by Neame ${ }^{5}$ in cases of early conjunctival tuberculosis.

Telangiectatic granulomata affecting the conjunctiva have been very fully teviewed by Hagedoorn ${ }^{6}$ comparatively recently.

\section{REFERENCES.}

1. Barrie, J. Stewart.-Glas. Med. Jl., Februarv, 1933.

2. MacRae, A.-Trans. Ophthal. Soc U.K., Vol. LIII, p. 594.

3. Beigelman, M. N.-Arch. of Ophthal., Vol. XIII, p. 188, 1935.

4. Würdemann, H. V.-Injuries of the Eye. 2nd edition, pp. $358401,468,499$, 1932.

5. Neame, H.-Trans. Ophthal. Soc. U.K., Vol. LIV, p. 92, 1934.

6. Hagedoorn, A.-Brit. Jl. of Ophthal., Vol. XVIII, p. 561, etc., 1934. 